\title{
Reverse Capitalism
}

\author{
Baruch Mevorach \\ Correspondence: Public Policy Department, Tel Aviv University, Israel \\ Received: December 14, 2015 Accepted: December 21, 2015 Online Published: December 25, 2015 \\ doi:10.11114/bms.v2i1.1267 \\ URL: http://dx.doi.org/10.11114/bms.v2i1.1267
}

\begin{abstract}
A rather strange end of history, in Fukuyama's terms (Fukuyama, 1992), is presented in the paper. Backed by the following six paradoxes, the entrepreneur and tycoon are beginning to return to the cozy lap of socialist ideology, while leaving behind their faithful worker, an unwilling prisoner of a cruel and alienated capitalistic ideology.

Entrepreneurs are living in a "No Risk Society", while faithful workers are prisoners of a "Full Risk Society" (Aharoni, 1981).

The six paradoxes, presented hereafter, are as follows:

1. "A negative correlation exists between the amount of time and energy devoted to an organization and the degree of ownership thereof".

2. "A negative correlation exists between the degree of identification with, involvement in, commitment to and loyalty to an organization and the degree of ownership thereof".

3. "Ownership of organizations is not acquired by one's own means. Owners are not really owners in the traditional sense of making purchases using their own money".

4. "The loss of the workplace is devastating for a worker, whereas the direct damage to the owners as a result of going out of business can sometimes be relatively marginal".

5. "In times of affluence, valuations are made on the stock exchange itself, which puts a high value on the companies traded in it; in times of depression, valuations are commissioned from outsiders, and they too traditionally put a high figure on the value of the company ordering the valuation".

6. "The price of a product is particularly high when sold up the hierarchy, from the private to the public company (upward generosity); the price of the same product is particularly low when sold down the hierarchy, from the public to the private company (downward stinginess)".
\end{abstract}

Keywords: full risk society, no risk society, reverse capitalism

\section{Introduction}

One of the fascinating phenomena taking shape before our eyes in recent years is, without a doubt, the transformation of owners into purely virtual figures in their own organizations.

Having found no systematic scientific explanation for this phenomenon in the academic management literature, it has occurred to me that the more appropriate source to have searched from the outset might have been the psychological literature, more particularly the kind that concerns itself with the personality of leaders and figures of illustrious accomplishments.

In the past, owners of the large business organizations in the western world took care to ensure that admiring biographers of their head-spinning success portrayed them as individuals actively involved in running their businesses. Further still, they were described as obsessive, even to the point where their centralistic management and hefty involvement were sometimes seriously detrimental to the very existence of their organizations (March \& Sutton, 1997; Mevorach, 2014).

The entrepreneurial organizational design, taught in every lecture on organizational design, described the business entrepreneur as an individual with a finger in every pie. The entrepreneur was involved in practically every business decision, and it was hard to convince him to confine himself to some area of specialization of his choosing and focus only on that. 
Owners' massive involvement in the active management of their businesses represents the "first wave" in the modern industrial organizational world.

Every MBA student is familiar with Henry Ford and Fredrick Taylor stories (Taylor, 1911, Hutchison, 2005). Taylor, inventor of the functional organizational design, worked hand in hand with his number one client Henry Ford.

In 1918, Ford handed over the presidency of Ford Motor Company to his son, Edsel Ford, even though he retained the final decision authority as chairman of Ford's board of directors.

The "move upstairs" and the control over a board of directors, whose roles comprised of: policy-setting, strategic planning, planning of control and supervision, executives' appointment and pay, the approval of financial statements, structural changes (takeovers and acquisitions, joint ventures, tender offers, etc.) and other matters considered fundamental to a company's business existence, marked the "second wave" in entrepreneurs' degree of daily involvement with their businesses.

As the owners went up to the "second floor", salaried professional managers with a distinguished track record in their respective functional management fields (finances, operations, marketing, human resources, etc.) were nominated in their stead. Each professional manager was given charge of a functional unit manned, in turn, by professionals in the relevant field.

The move "upstairs" allowed owners to relieve themselves of tedious, centralistic, everyday management tasks and free time for running the core of their business in the board's meeting rooms and advance other interests (Henry Ford's Senatorial race in 1918 for example). This represents the "second wave" in the modern industrial organizational world.

The move "upstairs" did not compromise performance in large organizations in any way. Rather, as it turns out, the salaried manager was often able to replicate and even surpass the owners' performance. This finding can be explained in several ways. In functional terms, the specialized manager can be argued to have professional advantages over the owners. In psychological terms, the professional manager, who is not an owner, has the advantage of being emotionally detached, allowing him to remain more cool-headed and financially-minded in making his moves. Another basic and relevant psychological explanation is, without a doubt, the employee's "hunger" and the simple fact that he is fighting for his and his family's economic survival, unlike the owner, who is striving for handsome ROI's and the ability to translate holdings into some level of profitability or another.

As is most commonly the case, it is the explanation combining the above and some other possible causes that is likely to be the one that comes closer to accounting for the phenomenon of the business success achieved by salaried managers.

The appetite of the salaried manager has been satiated by owners with the use of creative reward mechanisms: reward for cost savings, profit sharing, options and ownership shares. All were designed to fulfil the owners' desire to take home larger chunks of profits and drive up the prices of their market holdings in preparation for that much-awaited cash-in day.

The success of hired managers seems to have whetted owners' appetite for free time to such an extent that, in the "third wave", they have started to try removing themselves completely from the organizations they own.

\section{Suggested Paradoxes}

It is not a rarity today to see owners of big banks and holding companies who are not the least involved in managing their businesses. Instead, they hang out in cafes and trendy restaurants, manifesting their involvement in their holdings, at best, with a daily or weekly peek at the newspaper's stock page, to see the value of their holdings, which are traded in different stock exchanges worldwide.

See if you can convince the spirited MBA student to accept the following law of organizational behavior:

1. "A negative correlation exists between the amount of time and energy devoted to an organization and the degree of ownership thereof".

Put differently, of the three major stakeholders in organizations - owners, managers and workers-it is the workers who spend most of their time in the organization, thankful to their bosses for each extra hour of overtime the latter are willing to throw their way, whereas the owners will sometimes omit to even mention one or two holdings they possess, because, with so many of them under their belts, they cannot be bothered with individual holdings.

The new, "third wave" owners are getting close to God: Their spirit frequently pervades the organization, while their person seldom enters its territory, if at all. The "third wave" is characterized by the virtual presence of owners in particularly big organizations, in contrast to the physical presence that had characterized the "first wave" and the intellectual presence typical of the "second wave". 
Table 1. Characteristics of the three ownership waves in the organizational world

\begin{tabular}{lccc}
\hline \multicolumn{1}{c}{ Wave } & First & Second & Third \\
\cline { 1 - 3 } Owners' characteristic & & & \\
\hline Owners' presence & Physical & intellectual & virtual \\
\hline Owners' role & Active CEO & Director / Chairman & holdings trader \\
\hline Owners' involvement & Emotional & rational & speculative \\
\hline Owners' financing & Full & partial & none \\
\hline
\end{tabular}

Now, imagine the toughest, most estranged "first wave" owner. In his everyday work, he frequently rubbed shoulders with his workers, knew them by name and, willy-nilly, would naturally get closer to them and start developing friendly relationships with them at some level or other. The emotional involvement of "first-wave" owners made layoff procedures, justified as they may have been from a managerial and rational standpoint, relatively hard.

"Third wave" owners mainly rub shoulders with the employees and waiters of the cafes and restaurants in which they spend their time swapping, selling and buying all manner of holdings. They do not know their workers, and in some cases are even unable to state the exact number of people they employ in their cumulative holdings. When the name of the game is speculation rather than emotions, what is to prevent owners from completely ignoring their employees' well-being when faced with a lucrative offer to exchange, sell or buy a given holding?

Another interesting paradox relates to the degree of emotional involvement and of organizational commitment and loyalty. While workers and managers are held to emotional involvement in the organization on their part, the organization itself does not undertake, for its part, to be sensitive, committed and loyal towards them. Moreover, come the first "exit" opportunity, the owner is bound to exercise his holdings and abandon the fate of his loyal workers to the new owners, who resemble him in character.

This paradox can be formulated in another interesting law:

2. "A negative correlation exists between the degree of identification with, involvement in, commitment to and loyalty to an organization and the degree of ownership thereof".

It is not rare to see the photos change every few months in the meeting rooms of boards of directors in big holding companies, to reflect frequently changing holdings. Neither is it rare to find directors who have a hard time keeping up with the pace of changes in their holding company.

The workers down the echelon only have a single organization to relate to, whose name and location are very hard to forget, as are the physical and psychological energies it sucks out of them daily.

What occasioned the transition from the "first wave" to the "third wave" in the organizational world and the disappearance of owners of the largest organizations from their premises, the ones they once were so proud to own and to which they dedicated themselves body and soul, the ones they left for their heirs and spent every ounce of energy on?

One explanation could be their recognition of the fact that physical presence ("first wave") and intellectual presence ("second wave") presented no clearly proven advantages. Ownership of an organization in no way testifies to an ability to manage it, set its policies or plan its strategy.

Ownership of organizations has become its own profession. The transition made by tycoons into multiple holdings and diversification of holdings proves this argument. Keeping their distance from the organization is more useful to them than being physically and intellectually close to it.

Owners of organizations need to be distanced, alienated and alert; distanced and alienated from the organizations they own and alert to the noises and opportunities around them. Their energies need to be focused on the next purchase or sale.

Owners are supposed to be oriented towards their environment rather than their organization. The environment is where they will find their next business opportunity. Raising the value of their organization has become a task relegated to salaried directors, managers and employees.

The "third wave" is attended by another interesting phenomenon, which supports the argument that owners are alienated from and not involved in their organizations while being environment-oriented.

The "third wave" is characterized by owners not "bringing cash from home" or not "spending money out of pocket". Diluting an owner's private sources of capital might undermine further acquisitions and holdings, which is why he often looks for external credit. 
It is not uncommon to hear about owners of public companies who used generous bank credit to acquire huge companies, paying no more than five per cent of the purchase value itself out of pocket.

"Outside money" adds paradox to paradox:

3. "Ownership of organizations is not acquired by one's own means. Owners are not really owners in the traditional sense of making purchases using their own money".

We all know the joke about the small-time bank client who cannot sleep at night for fear of not being able to repay the bank his small overdraft. Unlike him, the debtor who has taken out a big loan from the bank sleeps like a baby, leaving the worries to his banker, who remains anxious day and night regarding his solvency.

The money is provided by others, the policy is determined by others, and the work is carried out by others. What remains for the owners to do? Just to be owners!

The damage caused to a worker as a result of managerial failure in his organization, going as far as bankruptcy, is often much greater than the damage sustained by the owner. Since ownership is acquired with generous credit and financial leveraging, the creditors, sometimes even governments, will see to it that the owner does not collapse completely.

Downsizing and layoffs of some of the workers will therefore be tolerated, all in the name of rescuing the capital of the owners and their creditors. As far as governments are concerned, partial efficiency measures, even if they mean letting some of the workers go, are preferable to the total liquidation of an organization, mass dismissals and bankruptcy of the owners, with serious damage to creditors entailed.

A worker's job is often the sole means available to him to fulfil his and his family's existential need. Losing it is often a threat to his physical existence and that of his nuclear family.

The damage to the owners is primarily to their image, but this too, owing to their many holdings, will not usually be particularly significant. If the liquidation of the organization was not attended by criminal offences, such as emptying the company of its assets, the owners are likely to be able to operate in the financial markets with just a little stain to their reputation.

Hence the next interesting paradox:

4. "The loss of the workplace is devastating for a worker, whereas the direct damage to the owners as a result of going out of business can sometimes be relatively marginal".

Business entrepreneurship, one of whose most prominent marks, at least according to conventional thinking, was the love of risk, is increasingly losing this unique trait, judging at least by actual results on the ground. The outcome of failed business entrepreneurship poses much more of a threat to the very existence of the worker employed therein in comparison to the owner, who had seemingly assumed the risk of establishing it to start with.

The business-financial risk assumed is loaded by owners of the large holding companies onto governments and various credit providers, who are concerned for the fate of the business entrepreneurs maybe even more than they are.

It would be interesting to examine, if this has not yet been done by various banking specialists, the amount of or lost or doubtful debt— - debt with a zero or low probability of being repaid —in both absolute and relative terms on the total amounts of credit extended to entrepreneurs as a whole on the one hand and employees as a whole on the other hand.

It can be reasonably assumed that the recent years of global economic recession have raised the relative rate of entrepreneurs' doubtful or lost debts to a great extent, but there is no doubt that the salaried worker's ability to repay debts, especially housing mortgages previously entered into, has also gone down considerably.

In times of affluence, the rising market capitalization of traded companies makes it possible to dilute owners' holdings slightly and pay back the generous bank loans. With companies making handsome profits, it is possible to take out generous dividends, which can also be used to recycle the debt and roll it over for the next acquisition.

Even in times of depression, though, there are many diverse mechanisms protecting owners. Many have the owners' best interest at heart, and would do anything to shield them from business and personal bankruptcy alike: (1) the government, with its fear of having more jobless added to the existing unemployment figures it sees in the economy; (2) the various creditors, who would do anything not to have the credit they had provided declared doubtful or lost debt, such that cannot be repaid and whose very size threatens the existence of the financial institution, the creditor itself; (3) professionals, such as auditors and various financing experts, are also quick to offer their help with beefed-up valuations, for the right money of course, which allow owners to avoid writing off losses on their holdings in different assets.

An auditor who fails to deliver the desired valuations seriously undermines his chances of being commissioned for other valuations. In doing so he is undermining his survivability, since demand for his services drops low anyway during times of economic depression compared to better times. 
The observer of valuation-work orders sees the next interesting paradox:

5. "In times of affluence, valuations are made on the stock exchange itself, which puts a high value on the companies traded in it; in times of depression, valuations are commissioned from outsiders, and they too traditionally put a high figure on the value of the company ordering the valuation".

Additional defense mechanisms that contribute to the survival of owners are the tender offer and the "the bottom-up sale" (e.g. from a private to a public company).

A tender offer allows owners, under certain legal conditions, to change their company's legal status from public to private. The tender offer tries to lure the small shareholder with some premium above the share's current market price in return for his willingness to sell the shares he holds.

While the tender offer means that owners must pay generous sums of money in buying back those percentages of shares they had previously sold to the public, in financial terms they are better off for it at the expense of the small shareholder. The reason for this is that the owners are probably aware of objective reasons that justify a relatively high value for the company they own, and which the public, due to the depression, is afraid to factor into the share price, or right out knows nothing about.

Needless to say, periods of plenty in the economy and the stock exchange are typically replete with public issues, usually overpriced by the owner, while periods of slump therein are replete with tender offers, which pull companies away from the public domain back into private anonymity.

The "bottom-up sale" is likewise mostly prevalent in times of depression. It involves the selling, at a premium, of (1) an owner's private assets to public companies belonging to same owner, or (2) assets belonging to one of the owners' public companies to another of his public companies.

Owners of public companies know how to exhibit a sense of fraternity and camaraderie during recessions and sell assets from one group to the other at prices higher than the going market rates.

Such generous exchanges are rather surprising in view of their toughness and ability to drive a hard bargain during normal times.

In normal times, lo and behold, the opposite phenomenon takes place, which we shall call "top-down sale". This phenomenon is accompanied by over-generosity on the part of public company owners towards private companies they own.

This leads to the sale of relatively high-priced assets at cheap prices and particularly convenient terms of payment by the owners of public companies to the private companies they own, to relatives and to themselves as private individuals.

The trivial and most illustrative example of a "top-down sale" is the sale of a public-company car to its owner after its leasing period at a very easy price. On the other hand, the sale of a private car from the owner to the company will almost always command an appropriate price, if not upwards.

The aforementioned, together with the "downward stinginess and upward generosity" can be encapsulated in the following interesting paradox:

6. "The price of a product is particularly high when sold up the hierarchy, from the private to the public company (upward generosity); the price of the same product is particularly low when sold down the hierarchy, from the public to the private company (downward stinginess)".

These transactions can also be done laterally between stakeholders in different companies who reach especially creative exchange, purchase and sale agreements, in particular during times of depression in the economy and the absence of real economic opportunities. Such roundabout transactions allow them to achieve handsome returns on their capital, all thanks to the camaraderie of their "bros" and on no justified economic grounds.

The defense mechanisms protecting the property and capital of the big holdings owner are diversified. Some are tax-based, others credit-based, and some speculative-amical.

\section{And White-Collar Workers Too}

White-collar workers were quick to respond to the development of the "third wave" mentioned above (their response is hereinafter referred to as the "second work wave"). The white-collar worker possessing skills that are in demand in the labor market nowadays tends to spread risks of his own initiative and diversify his sources of employment in "patchwork" mode, allowing him to better deal with the possible risks of frequent layoffs in an extremely competitive and speculative world.

The work week of the white-collar worker in the "second work wave" is divided between a number of employers, 
employments and different methods of employment.

The white-collar worker in "the second work wave" reduces his dependence on a single employer. He acts as an independent advisor for various organizations, as a part-time worker for one number of hours or another for other organizations.

The "patchwork" method has many tax advantages, allowing the worker to plan the tax levels he pays on the work he does in a way that is more intelligent and worthwhile for him.

Most importantly, the white-collar worker's dependence on the arbitrariness of the owners, whom he often does not know, is diminishing. As owners reduced their level of emotional involvement and increased their level of speculation in their various holdings, the white-collar worker became less emotionally involved in one single workplace, the individual "patch" in the "patchwork" he has sewn for himself. The white-collar worker "trades" his various jobs just as the owners do with their various holdings.

Computer and telecommunication technology allows a very loose physical link to exist between organizations and their employees and compensates, to some extent, the more vulnerable worker for arbitrary layoffs by the owners of the organization in which he is employed.

Table 2. Characteristics of both waves of white-collar/professional work in the organizational world

\begin{tabular}{|c|c|c|}
\hline Wave & First & Second \\
\hline \multicolumn{3}{|l|}{ Work characteristic } \\
\hline Scope of job & full & part-time \\
\hline Physical location & organization & home / office \\
\hline Movement between organizations & forced & mainly voluntary \\
\hline Employee involvement & emotional & rational / speculative \\
\hline Employment status & employee & employee and/or independent \\
\hline
\end{tabular}

The competitive white-collar worker in the "second work wave" in many cases arranges his occupational "patchwork" in descending order of extrinsic and intrinsic rewards available in his various places of employment, deciding whether to leave or stay accordingly.

The most extreme example of "second work wave" characteristics is inherent in chairmen of public companies' boards of directors who are not in-house salaried workers of the companies they head.

They are defined, for income-tax purposes, as consultants to the companies they head, using invoices to charge these companies their fees, as would any external consultant.

This kind of employment of the most senior non-owner managers and directors in organizations represents a mutual interest. The owners are keen to save themselves the social contributions required under other modalities of employment, while the worker or professional manager prefer billing the company expensive hours while managing themselves their contributions towards pensions and various insurances through independent consultancies they own.

The "hot desking" employment method, which once referred to flexible and part-time employment of salaried workers in various organizations, is currently shifting to the homes of white-collar workers.

If the term "hot desking" once referred to a number of employees working around one table, today it is becoming increasingly characteristic of a different format: white-collar professionals seated at the home "hot desk"- a single desk from which they work for several organizations they serve.

The white-collar worker, perhaps in imitation of the big holding owners, is also becoming, like them and to a large extent, an entirely virtual and emotionally-detached figure in the organizations to which he provides consulting services in different areas.

Various tax reforms privileged professional freelance work over salaried professional work in two respects. One was the ability to withdraw low tax dividends from a company without paying any personal income tax on them. The other was the substantial tax differential between corporate and personal taxes, in favor of corporate taxes of course.

The white-collar professional is in fact turning into a holding company, except that his holdings are his attention and intellect as divided between different companies for which he works and acts as consultant to.

The considerations made by the white-collar worker in deciding whether to stay or leave, and whether to reduce or increase his contribution to a given organization, are somewhat similar the those made by owners of big holding companies, except that instead of relating to returns on capital, they have to do with returns on the intellectual capital he 
provides to his various holdings.

The white-collar professional and the owner of a big holding company are a relatively rare breed of people possessing financial capital and intellectual capital that are in demand. The first is protected by the potential intellectual damage that his departure would cause to the company in which he is employed; the second is protected by the potential damage of his departure to the company, to creditors, and to the state in general.

\section{Epilogue}

The truly defenseless and the true risk takers are, ultimately, the line and service workers, whose work is not unique or particularly critical for their organization. They can be quite easily replaced, and this can be done relatively fast without much investment in training and development.

This kind of employee is increasingly losing the state's protection, on which he used to rely, in an alienated capitalistic world geared now, more than ever, towards protecting owners of substantial capital. It is during the very period when real unemployment figures in the western world are and will probably be on the rise that the salaried worker is losing significant insurance components that once protected him, and all this in favor of the tycoon who is harnessing ever greater state resources in favor of his own financial protection.

The end of ideology is to a great extent the end of the legitimacy given to the masses to enjoy various insurance mechanisms and the strengthening of the same legitimacy for the few initially well to do, whose attachments to and availability in the organizations they own are diminishing (Paradoxes 1 and 2 above).

A stranger observing the capitalistic western culture will witness an interesting phenomenon with far-reaching implications. The tycoon is the new wretch, who receives all manner of state and other protections while leaving his loyal worker more or less devoid of state protections, and significantly so compared to the past.

This is, undoubtedly, an upside-down world. Owners are getting closer to God. They have left their organizations, lost touch with their employees, and are willing, today more than ever, to consider downsizing as an initial and primary tool for dealing with economic crises. Their loyal employees invest more and more in trying to cope with the global financial crisis, while losing layers of defense and insurance such as salary levels, adequate social benefits, the protection of worker committees and trade unions and suffering from reduced caution in massive and rushed dismissals.

The owners, being entirely virtual figures in their organizations, will be able to devote more and more free time to governmental interfaces, in order to acquire increasingly more defenses and insurances. The junior employee will give up increasingly more time and money resources to ensure his employment while increasingly losing different kinds of defenses and insurances.

It is the strange end of history indeed. The entrepreneur and tycoon is beginning to return to the cozy lap of socialist ideology, while leaving behind his faithful worker an unwilling prisoner of a cruel and alienated capitalistic ideology that robs him of intellectual, time and money resources in his efforts to survive in a world of employment that is possibly more ruthless and competitive than the world of organizations and their ownership.

\section{Bibliography}

Aharoni, Y. (1981). The No-Risk Society, Chatam House. ISBN 10:0934540063/ISBN 13:9780934540063

Fukuyama, F. (1992). The End of History and the Last Man, Free Press. ISBN: 0-02-910975-2

Hutchison, M. (2005). Big Ideas in US History. Kerry Gordonson, Editor; Dr. Aaron Willis, Project Coordinator, Culver City, California: Social Studies School Service. ISBN: 1-56004-206-0

March, J. G., \& Robert, I. S. (1997). Organizational Performance as a Dependent Variable. Organizational Science, 8(6), 698-706. http://dx.doi.org/10.1287/orsc.8.6.698

Mevorach B. (2014). Soldiers and Priests in Business Administration. Quality and Quantity, 6, 2649-2654. http://dx.doi.org/10.1007/s11135-014-0133-5

Taylor, F. W. (1911). Principles of Scientific Management, Harper \& Brothers publishers. ISBN 0-415-27982-8 (set) ISBN 0-415-27983-6 (Vol. 1) 